\title{
Modeling of Unsteady Processes in Penning Gas Discharge Plasma using PIC-MCC Method
}

\author{
Alexey Dikalyuk ${ }^{1,2,3}$, Gumennov Vladislav ${ }^{1,2,3}$
}

${ }^{1}$ Dukhov Research Institute of Automatics, 22, Sushchevskaya st., Moscow, 127055, Russia

${ }^{2}$ Institute for Problems in Mechanics Russian Academy of Sciences, Moscow, 119526, Russia

${ }^{3}$ Moscow Institute of Physics and Technology, Dolgoprudny, 141700, Russia

aleks.dikalyuk@gmail.com

\begin{abstract}
Modeling of temporal evolution of Penning gas discharge plasma in molecular hydrogen at pressure 0.8 mtorr, anode voltage $800 \mathrm{~V}$ and axial magnetic field $330 \mathrm{G}$ is performed in the paper. Simulation is carried out using 2D/3V axisymmetric electrostatic PIC-MCC method. Distinct feature of this work is the addition of dissociative ionization process to kinetic model of Penning gas discharge in molecular hydrogen. In the paper temporal evolution of electrostatic potential, field, charged particles number densities and temperatures in gas discharge chamber are given.
\end{abstract}

Keywords: molecular hydrogen, atomic hydrogen, Penning discharge, low pressure, external magnetic field.
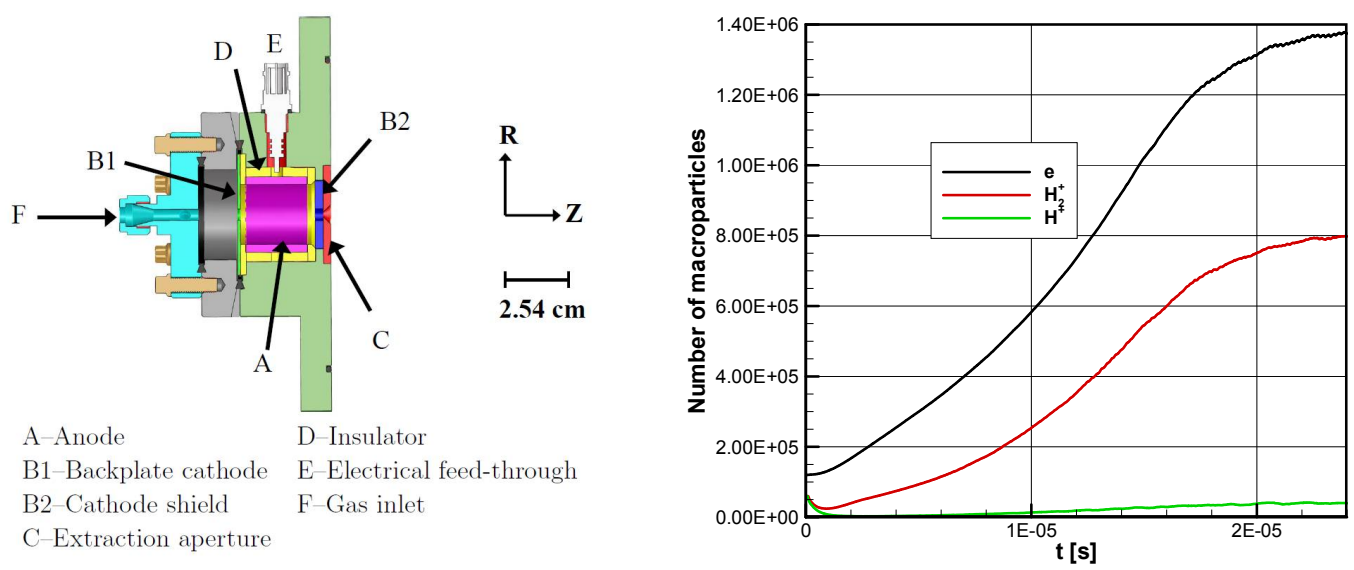

Fig. 1. Schematic view of the experimental setup (figure is taken from [1], on the left), temporal evolution of number of macroparticles in numerical simulation (on the right)
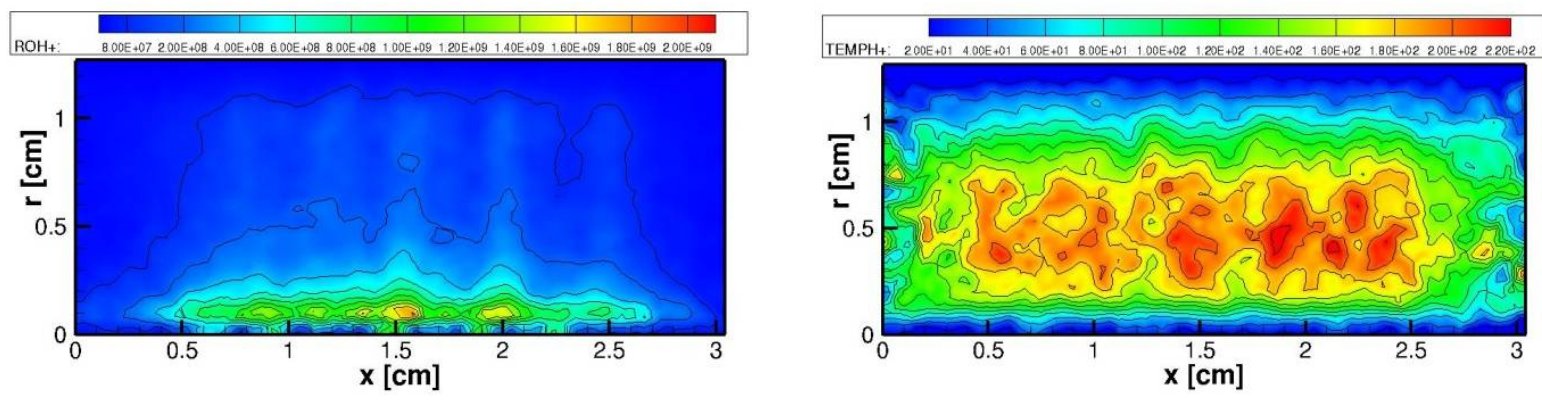

Fig. 2. Distribution of number density $\left[\mathrm{cm}^{-3}\right]$ (on the left figure) and temperature $[\mathrm{eV}]$ (on the right figure) of atomic hydrogen in the Penning gas discharge plasma 


\section{Introduction}

Penning discharge is high-voltage low-pressure glowing discharge existing in the presence of external magnetic field. In 1937 low pressure manometer was invented based on it [2] and since then this discharge has been used in numerous practical applications [3].

Penning discharge is known for a long time; however, there are few studies (both experimental and theoretical) aimed at investigation of its spatial structure [4-12]. There are even less researches dedicated to analysis of plasma chemical reactions in the Penning gas discharge [13-15].

In this paper numerical simulation of Penning discharge in molecular hydrogen is performed. Discharge parameters experimentally investigated in University of California, Berkley was used for conducted modeling. The model of Penning gas discharge proposed in [9] supplemented by the process of dissociative ionization is used for in the study, which is distinctive feature of the work. It allows to investigate influence of various parameters such as anode voltage, pressure, magnetic field on the amount of atomic hydrogen that is formed while the gas discharge exists. Results of numerical simulation are presented as animated files, which show the temporal evolution of two-dimensional distributions of electrostatic potential, field, number density and temperature of charged particle species in the gas discharge chamber.

\section{Video description}

In the fig. 1 scheme of experimental setup, intended for the investigation of Penning gas discharge in molecular hydrogen, is presented [1]. Cylindrical anode in the center of the scheme is shown in purple color. Cathode and anticathode are shown in blue and green color and situated in the opposite ends of gas discharge chamber. Electrodes are made of aluminum. There is an orifice in the anticathode. Magnetic field is created by means of current coil and is almost uniform in the bulk of discharge chamber.

Experimental study of the Penning gas discharge has been performed at the following parameters: working gas is $\mathrm{H}_{2}$, pressure is $0.8 \div 1.0$ mTorr, anode voltage is $600 \div 800 \mathrm{~V}$, axial magnetic field is $300 \div 400 \mathrm{G}$, discharge current is $4 \div 5 \mathrm{~mA}$, length and inner diameter of the anode is $2.54 \mathrm{~cm}$, volume of the discharge chamber is $12.9 \mathrm{~cm}^{3}$. In the experiments, discharge current was recorded. Composition of the beam, leaving the gas discharge chamber, was measured by means of the mass spectrometry. Results of the measurements indicate that the fraction of ionized hydrogen atoms in the beam is about $5 \div 10 \%$.

Numerical simulation of the system described above is carried out using the model described in [9] at the following parameters: pressure of the molecular hydrogen $0.8 \mathrm{mTorr}$, anode voltage $800 \mathrm{~V}$, axial magnetic field $0.033 \mathrm{~T}$. Detailed description of the model implementation is given in $[16,17]$. Process of dissociative ionization of $\mathrm{H}_{2}$ molecules in collision with electrons was introduced in the baseline model of the Penning discharge in molecular hydrogen [9]. Cross-section of the process was taken from [18].

Animation files (animation time corresponds to the physical time $\sim 26 \mathrm{mks}$ ) show the results of numerical simulation of transient processes while gas discharge plasma approaches to steadystate:

1) $\mathrm{Fi}$ - name of the animation file, which demonstrate temporal evolution of spatial distribution of electrostatic potential, [V];

2) $\mathrm{Ez}$ - name of the animation file, which demonstrate temporal evolution of spatial distribution of axial component of electric field, [V/cm];

3) $\mathrm{Er}$ - name of the animation file, which demonstrate temporal evolution of spatial distribution of radial component of electric field, [V/cm];

4) absE - name of the animation file, which demonstrate temporal evolution of spatial distribution of absolute value of electric field, $[\mathrm{V} / \mathrm{cm}]$; 
5) ROe - name of the animation file, which demonstrate temporal evolution of spatial distribution of number density of electrons in computational domain, $\left[\mathrm{cm}^{-3}\right]$;

6) Te - name of the animation file, which demonstrate temporal evolution of spatial distribution of temperature of electrons in computational domain, $[\mathrm{eV}]$;

7) $\mathrm{ROH} 2+-$ name of the animation file, which demonstrate temporal evolution of spatial distribution of number density of molecular hydrogen ions in computational domain, $\left[\mathrm{cm}^{-3}\right]$;

8) $\mathrm{TH} 2+-$ name of the animation file, which demonstrate temporal evolution of spatial distribution of temperature of molecular hydrogen ions in computational domain, [eV];

9) $\mathrm{ROH}+-$ name of the animation file, which demonstrate temporal evolution of spatial distribution of number density of atomic hydrogen ions in computational domain, $\left[\mathrm{cm}^{-3}\right]$;

10) $\mathrm{TH}+-$ name of the animation file, which demonstrate temporal evolution of spatial distribution of temperature of atomic hydrogen ions in computational domain, [eV];

Based on the data presented above one can estimate fraction of ionized hydrogen atoms in the simulation. In the considered case this value is $\sim 4.7 \%$, which is in agreement with experimental measurements.

\section{Conclusion}

In the study results of numerical simulation of Penning discharge in molecular hydrogen obtained using the PIC-MCC method accounting for the process of dissociative ionization are shown. Presented animation files allow to get an idea of the unsteady phase of gas discharge existence.

\section{Acknowledgements}

The presented study was supported by the Russian Science Foundation project № 16-1110275 .

\section{References}

1. Sy A.V. Advanced Penning-type source development and passive beam focusing techniques for an associated particle imaging neutron generator with enhanced spatial resolution Berkley: University of California, 2013.

2. Penning F.M.. Ein neues manometer fur niedrige gasdrucke, insbesondere zwischen $10^{-3}$ and $10^{-5} \mathrm{~mm}$ // Physica. 1937. Vol. 4. Iss. 2. pp. 71-75.

3. Rovey J.L., Ruzic B.P., Houlahan T.J. Simple Penning Ion Source for Laboratory Research and Development Applications // Review of Scientific Instruments. 2007. Vol. 78. 106101-1 - 106101-3.

4. Surzhikov S.T. Application of the modified drift-diffusion theory to study of the two-dimensional structure of the penning discharge // AIAA paper. 2015. AIAA 2015-1832.

5. Surzhikov S.T. 2017 Two-dimensional of the Penning discharge in a cylindrical chamber with the axial magnetic field Technical Physics 621177.

6. Surzhikov S.T. Numerical simulating the two-dimensional structure of the Penning discharge using the modified drif-diffusion model // Journal of Physics: Conference Series. 2017. Vol. 815. 012004.

7. Surhzikov S.T. 2017 Two-dimensional structure of Penning discharge in a cylindrical chamber with axial magnetic field at pressure 1 Torr Technical Physics Letter $\mathbf{4 3} 169$.

8. Dikalyuk A.S., Kuratov S.E. Numerical Investigation of Penning Discharge Characteristics using 2D/3V Particle-In-Cell Method // Journal of Physics: Conference Series. 2017. Vol. 815. 012001.

9. Dikalyuk A.S. Validation of Numerical Model of Penning Gas Discharge based on 2D/3V PIC-MCC method // Journal of Physics: Conference Series. 2018. Vol. 1009. 012023.

10. Gumennov V.O., Dikalyuk A.S. Calculation a Penning plasma discharge characteristics taking into account the magnetic field produced by annular magnets // Journal of Physics: Conference Series. 2018. Vol. 1009. 012025. 
11. Surzhikov S.T., Kuratov S.E.Drift-diffusion model of the Penning discharge at pressures about 1 Torr // Physical-Chemical Kinetics in Gas Dynamics. 2014. Vol. 15. Iss. 5. http://chemphys.edu.ru/issues/2014-15-5/articles/252/

12. Mamedov N.V., Schitov N.N., Kanshin I.A. Investigation of the Dependency of Penning Ion Source Operational Characteristics on its Geometric Parameters // Physical-Chemical Kinetics in Gas Dynamics. 2015. Vol. 16. Iss. 4. http://chemphys.edu.ru/issues/2015-16-4/articles/590/

13. Storozhev D.A. Numerical simulation of the kinetics of ionization and dissociation of hydrogen in Penning discharge plasma in the LTE // Physical-Chemical Kinetics in Gas Dynamics. 2014. Vol. 15. Iss. 3. http://chemphys.edu.ru/issues/2014-15-3/articles/229/

14. Storozhev D.A., Surzhikov S.T., Kuratov S.E. Numerical simulation of dissociation kinetics in the penning discharge plasma using 2D modified drift-diffusion model // Proc. of 55 ${ }^{\text {th }}$ AIAA Aerospace Meeting, AIAA SciTech Forum. 2017. AIAA 2017-1966.

15. Storozhev D.A., Kuratov S.E. Numerical simulation of the kinetics of dissociation and ionization of molecular hydrogen in the penning discharge plasma with the use of the reduced kinetic model // Journal of Physics: Conference Series. 2017. Vol. 815. 012002.

16. Dikalyuk A.S. Development of Particle-In-Cell Solver for Numerical Simulation of Penning Discharge $/ /$ Proc. of $55^{\text {th }}$ AIAA Aerospace Meeting, AIAA SciTech Forum. 2017. AIAA 2017-0842.

17. Dikalyuk A.S., Kuratov S.E. Numerical Modeling of Plasma Devices by the Particle-In-Cell Method on Unstructured Grids // Mathematical Models and Computer Simulations. 2018. Vol. 10. Iss. 2. Pp. 198-208.

18. Yoon J.-S., Song M.-Y., Han J.-M., Hwang S.H., Chang W.-S., Lee B.J., Itikawa Y. Cross Sections for Electron Collisions with Hydrogen Molecules // J. Phys. Chem. Ref. Data. 2008. Vol. 37. No. 2. Pp. 913-931. 


\title{
Моделирование нестационарных процессов в разряде Пеннинга с использованием метода PIC-MCC
}

\author{
А.С. Дикалюк ${ }^{1,2,3}$, В.О. Гуменнов ${ }^{1,2,3}$ \\ ${ }^{1}$ Всероссийский научно-исследовательский институт им. Н.Л. Духова, \\ Россия, Москва, 127055, Сущевская ул., д. 22 \\ ${ }^{2}$ Институт проблем механики им. А.Ю. Иилинского РАН, \\ Россия, Москва, 119526, просп. Вернадского, д. 101, корп. 1 \\ ${ }^{3}$ Московский физико-технический институт, \\ Россия, Долгопрудньй, 141700, Институтский пер., д. 9 \\ aleks.dikalyuk@gmail.com
}

\begin{abstract}
Аннотация
В работе выполнено моделирование временной эволюции плазмы разряда Пеннинга в молекулярном водороде при $p=0.8$ мторр, анодном напряжении $800 \mathrm{~B}$ и внешнем осевом магнитном поле 330 Гс. Результаты получены с помощью 2D/3V метода частиц-в-ячейках. Элементарные процессы моделируются методом Монте-Карло. Отличительным свойством этой работы является включение процесса диссоциативной ионизации в модель разряда Пеннинга. Представлена временная эволюция электростатического потенциала, поля, плотности заряженных частиц и их температуры.
\end{abstract}

Ключевые слова: молекулярный водород, атомарный водород, разряда Пеннинга, низкие давления, внешнее магнитное поле.
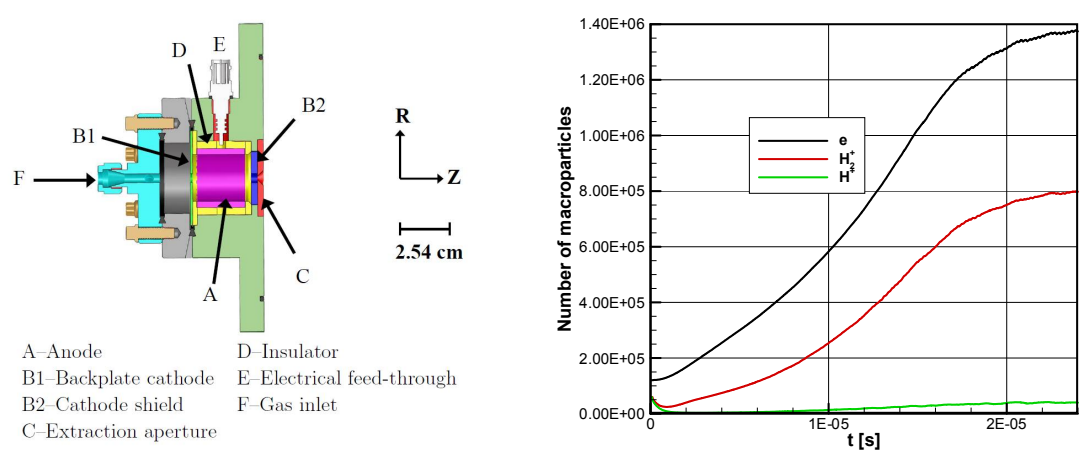

Рис. 1. Схематическое изображение экспериментальной установки (взята из [1], слева), временная эволюция числа макрочастиц в расчете (справа)
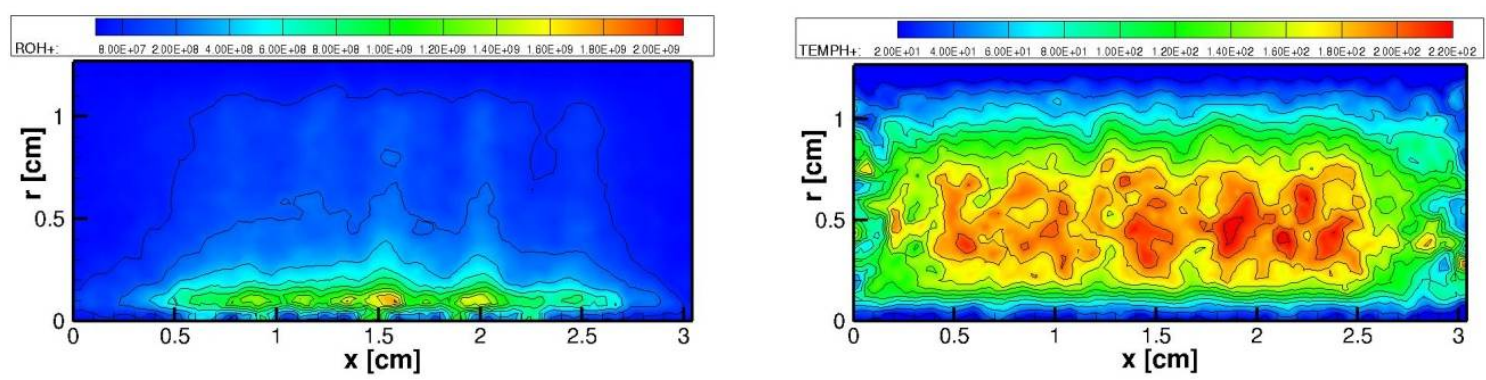

Рис. 2. Распределение плотности $\left[\mathrm{cm}^{-3}\right]$ (слева) и температуры [эВ] (справа) ионов водорода 


\section{1. Введение}

Разряд Пеннинга является высоковольтным тлеющим разрядом низкого давления, помещенным во внешнее магнитное поле. В 1937 году на его основе был создан манометр [2] и с тех пор этот разряд нашел широкое практическое применение [3].

Несмотря на то, что разряд Пеннинга известен достаточно давно, существует мало (как экспериментальных, так и теоретических) работ, направленных на изучение его пространственной структуры [4-12]. Единичные работы посвящены исследованию плазмохимических превращений в газовом разряде Пеннинга [13-15].

В данной работе выполнено численное моделирование разряда Пеннинга в молекулярном водороде, изученном экспериментально в университете Калифорнии, Беркли. Модель разряда Пеннинга, предложенная в [9] дополнена процессом диссоциативной ионизации, что является отличительной особенностью моделирования, выполненного в данной работе, и, в перспективе, позволяет исследовать влияние параметров разряда на количество атомарного водорода, нарабатываемого при его горении. Результаты численного моделирования представлены в виде анимационных файлов, демонстрирующих временную эволюцию двухмерных распределений электростатического потенциала, полей, плотностей и температур заряженных частиц в газоразрядной камере.

\section{2. Описание видео}

На рис. 1 представлена схема экспериментальной установки, предназначенная для исследования разряда Пеннинга в молекулярном водороде [1]. Цилиндрический анод в центре схемы отмечен сиреневым цветом. Катод и антикатод изображены синим и зеленым цветом и находятся в торцах газоразрядной камеры. Электроды изготовлены из алюминия. В антикатоде имеется отверстие. Магнитное поле создается катушкой с током и считается практически однородным в объеме разрядной камеры.

Экспериментальные исследования были выполнены при следующих параметрах: рабочий газ $-\mathrm{H}_{2}$, давление $0.8 \div 1.0$ мторр, напряжение на аноде $-600 \div 800 \mathrm{~B}$, осевой магнитное поле $300 \div 400$ Гс, ток разряда $3 \div 4$ мА, длина и внутренний диаметр анода -2.54 см, объем разрядной камеры - $12.9 \mathrm{~cm}^{3}$. В экспериментах регистрировался ток разряда, а также проводились масс-спектрометрические измерения состава пучка, выходящего из газоразрядной камеры. Отмечается, что доля ионизованных атомов водорода в пучке обычно составляет $5 \div 10 \%$.

Численное моделирование описанной выше системы выполнено с использованием модели, описанной в [9], при следующих параметрах: давление $\mathrm{H}_{2} p=0.8$ мторр, напряжение на аноде $V=800 \mathrm{~B}$, осевое магнитное поле $B=0.033$ Тл. Детали реализации метода частиц-вячейках приведены в работах $[16,17]$. Процесс диссоциативной ионизации молекул $\mathrm{H}_{2}$ при столкновении с электронами был включен в базовую модель разряда Пеннинга в молекулярном водороде [9]. Сечение процесса взято из [18].

Анимационные файлы (время анимации соответствует физическому времени 26 мкс) показывают результаты численного моделирования переходных процессов при стремлении газоразрядной плазмы к стационарному состоянию:

1) $\mathrm{Fi}$ - имя анимационного файла, демонстрирующего временную эволюцию пространственного распределения электростатического потенциала, [В];

2) $\mathrm{Ez}$ - имя анимационного файла, демонстрирующего временную эволюцию пространственного распределения осевой компоненты электрического поля, [В/см];

3) $\mathrm{Er}$ - имя анимационного файла, демонстрирующего временную эволюцию пространственного распределения радиальной компоненты электрического поля, [B/см];

4) absE - имя анимационного файла, демонстрирующего временную эволюцию пространственного распределения абсолютного значения электрического поля, [B/см]; 
5) $\mathrm{ROe}$ - имя анимационного файла, демонстрирующего временную эволюцию пространственного распределения плотности числа электронов в расчетной области, $\left[\mathrm{cm}^{-3}\right]$;

6) Те - имя анимационного файла, демонстрирующего временную эволюцию пространственного распределения температуры электронов в расчетной области, [эВ];

7) $\mathrm{ROH} 2+$ - имя анимационного файла, демонстрирующего временную эволюцию пространственного распределения плотности числа молекулярных ионов водорода в расчетной области, $\left[\mathrm{cm}^{-}\right]$;

8) ТН2+ - имя анимационного файла, демонстрирующего временную эволюцию пространственного распределения температуры молекулярных ионов водорода в расчетной области, [эВ];

9) $\mathrm{ROH}+$ - имя анимационного файла, демонстрирующего временную эволюцию пространственного распределения плотности числа атомарных ионов водорода в расчетной области, $\left[\mathrm{cm}^{-3}\right]$;

10) ТН+ - имя анимационного файла, демонстрирующего временную эволюцию пространственного распределения температуры атомарных ионов водорода в расчетной области, [эВ];

Исходя из представленных данных, можно определить долю ионизованных атомов водорода. В данном случае эта величина составляет $\sim 4.7 \%$, что находится в хорошем соответствии с данными эксперимента.

\section{3. Заключение}

В работе представлены результаты численного моделирования разряда Пеннинга в молекулярном водороде методом частиц-в-ячейках с учетом процесса диссоциативной ионизации. Представленные анимационные файлы позволяют получить представление о нестационарной фазе горения разряда.

\section{Благодарности и ссылки на гранты}

Работа выполнена при поддержке Российского научного фонда (грант № 16-11-10275).

\section{Литература}

1. Sy A.V. Advanced Penning-type source development and passive beam focusing techniques for an associated particle imaging neutron generator with enhanced spatial resolution Berkley: University of California, 2013.

2. Penning F.M.. Ein neues manometer fur niedrige gasdrucke, insbesondere zwischen $10^{-3}$ and $10^{-5} \mathrm{~mm}$ // Physica. 1937. Vol. 4. Iss. 2. pp. 71-75.

3. Rovey J.L., Ruzic B.P., Houlahan T.J. Simple Penning Ion Source for Laboratory Research and Development Applications // Review of Scientific Instruments. 2007. Vol. 78. 106101-1-106101-3.

4. Surzhikov S.T. Application of the modified drift-diffusion theory to study of the two-dimensional structure of the penning discharge // AIAA paper. 2015. AIAA 2015-1832.

5. Суржиков С.Т. Двумерная модель разряда Пеннинга в цилиндрической камере с осевым магнитным полем // Журнал технической физики. 2017. Т. 87. Вып. 8. С. 1165-1176.

6. Surzhikov S.T. Numerical simulating the two-dimensional structure of the Penning discharge using the modified drif-diffusion model // Journal of Physics: Conference Series. 2017. Vol. 815. 012004.

7. Суржиков С.Т. Двухмерная структура разряда Пеннинга в цилиндрической камере с осевым магнитным полем при давлении порядка 1 торр // Письма в ЖТФ. 2017. Т. 43. Вып. 3. С. 64-71.

8. Dikalyuk A.S., Kuratov S.E. Numerical Investigation of Penning Discharge Characteristics using 2D/3V Particle-In-Cell Method // Journal of Physics: Conference Series. 2017. Vol. 815. 012001.

9. Dikalyuk A.S. Validation of Numerical Model of Penning Gas Discharge based on 2D/3V PIC-MCC method // Journal of Physics: Conference Series. 2018. Vol. 1009. 012023. 
10. Gumennov V.O., Dikalyuk A.S. Calculation a Penning plasma discharge characteristics taking into account the magnetic field produced by annular magnets // Journal of Physics: Conference Series. 2018. Vol. 1009. 012025.

11. Суржиков С.Т., Куратов С.Е. Диффузионно-дрейфовая модель Пеннинговского разряда при давлениях порядка 1 Торр//Физико-химическая кинетика в газовой динамике. 2014. Т.15. Вып.5. http://chemphys.edu.ru/issues/2014-15-5/articles/252/

12. Щитов Н.Н., Каньшин И.А., Мамедов Н.В. Исследование зависимостей эксплуатационных характеристик источника ионов Пеннинга от его геометрических параметров // Физико-химическая кинетика в газовой динамике. 2015. Т. 16. Вып. 4. http://chemphys.edu.ru/issues/2015-164/articles/590/

13. Сторожев Д.А. Численное моделирование кинетики ионизации и диссоциации водорода в плазме разряда Пениннга в приближении ЛТР // Физико-химическая кинетика в газовой динамике. 2014. Т.15. Вып. 3. http://chemphys.edu.ru/issues/2014-15-3/articles/229/

14. Storozhev D.A., Surzhikov S.T., Kuratov S.E. Numerical simulation of dissociation kinetics in the penning discharge plasma using 2D modified drift-diffusion model // Proc. of 55 ${ }^{\text {th }}$ AIAA Aerospace Meeting, AIAA SciTech Forum. 2017. AIAA 2017-1966.

15. Storozhev D.A., Kuratov S.E. Numerical simulation of the kinetics of dissociation and ionization of molecular hydrogen in the penning discharge plasma with the use of the reduced kinetic model // Journal of Physics: Conference Series. 2017. Vol. 815. 012002.

16. Dikalyuk A.S. Development of Particle-In-Cell Solver for Numerical Simulation of Penning Discharge $/ /$ Proc. of $55^{\text {th }}$ AIAA Aerospace Meeting, AIAA SciTech Forum. 2017. AIAA 2017-0842.

17. Дикалюк А.С., Куратов С.Е. Реализация метода частиц-в-ячейках на неструктурированных сетках для численного моделирования плазменных устройств // Математическое моделирование. 2017. T. 29. № 9. C. 33-48.

18. Yoon J.-S., Song M.-Y., Han J.-M., Hwang S.H., Chang W.-S., Lee B.J., Itikawa Y. Cross Sections for Electron Collisions with Hydrogen Molecules // J. Phys. Chem. Ref. Data. 2008. Vol. 37. No. 2. Pp. 913-931. 